\title{
LESSONS FROM BEST PRACTICES FOR ENGLISH LANGUAGE EDUCATIONAL REFORM IN THAILAND
}

\author{
Tanes Liengleam \\ Amporn Sa-ngiamwibool \\ Email:amporn_kai@yahoo.com \\ Shinawatra International University, Thailand
}

\begin{abstract}
Lessons from other countries where digital technology is integrated into English classroom will shed lights to digital Thailand. This study, therefore, analyzed the best practices to extract and describe key success factors that could help increase national competitiveness. The conclusion of the study was drawn from an interpretive analysis and synthesis of the review of literature. Five purposefully selected best practices included Finland, Norway, the Netherlands and South Korea. This was a documentary study. The results revealed that key success that all these best practice countries share includes these ten issues: free, accessible, equalized education, ICT in English education, starting learning English in early age, professional development for teachers, stress on qualification of teachers, teacher compensations and welfares, small class size, assessment and testing reform and homework reform. Policy implications indicate that if the Thai government want to reach the educational efficiency of the best practice countries, it should take these issues into consideration. Future inquiry should include more countries to get a wider, more practical and more insightful holistic scope of the study.
\end{abstract}

Keywords: English language education reform, best practice, policy implications

\section{INTRODUCTION}

Due to the advance of technology, English has become a world language and this has greatly affected the English language teaching and learning of all countries including Thailand. In the past few decades, Thailand has been trying to reform its education. Lifelong learning has been introduced as a new direction of Thailand's educational reform. Still, there have been numerous challenges to this country in its 
attempt to reform the English language teaching and learning in Thailand, especially the challenges regarding to the use of English for communication.

A review of prior research revealed some crucial challenges of English for communication which can impede the progress of Thailand economically, socially and culturally. The challenges included several factors but, practically, one of the most crucial challenges lies in the ability of Thais to use of English for international communication. Arunee Wiriyachitra1 (2002) points out that Thais' level of English proficiency is low in comparison with many countries in Asia (e.g. Malaysia, Philippines, and Singapore). In addition to this, the former Minister of University Affairs of Thailand (a speech given on March 6, 2000) revealed that the average TOEFL scores of Thais are at the same level of those of Mongolians but higher than those of North Koreans and Japanese.Despite of the attempts to reform the education of the whole nation for the past decade, a recent survey revealed a shocking record that strongly supports the history. According to EF English Proficiency Index 2015which annually ranks countries and territories based on test data from more than 910,000 adults who took EF online English test, Thailand was ranked no. 62 out of 70 countries and was marked as "very low proficiency."

Findings of prior study support the fact. For example, de Segovia, L. P., \& Hardison, D. M. (2009)who investigated the reform policy behind and implementation of the National Education Act in Thailand which mandated a transition from teacher- to learner-centered instruction for all subjects including English found that teachers were concerned about their English proficiency, insufficient training, and inadequate resources and professional support.Similarly, Kirkpatrick, R. (2012) notes that the current Thai education system is well funded but is not producing sufficient graduates skilled in English. This low

\footnotetext{
${ }^{1}$ Arunee Wiriyachitra was former ThaiTESOL President and a current executive committee of ThaiTESOL
} 
proficiency will undeniably cause damages to its economic competitiveness in regional and global markets.

This low proficiency is a result of numerous factors. One of the major factors is that the teaching and learning of English in Thailand has exclusively been occupied by pedagogical principles and techniques. English in real-life contexts outside the classroom is rarely included and thus communicative enhancement is ignored. To illustrate this, Methitham, P., \& Chamcharatsri, P. B. (2011) noted that, in Thai education, English language has been gaining its pre-eminence role since 18 th century but many research studies have been focused only on how to apply a set of pedagogical principles and techniques in the local classroom, in which social, cultural, and political dimensions have been excluded from those studies.

One of the most important key factors that greatly affect all involving in the quality of language teaching and learning in Thailand but has been ignored is the national policy, especially the policy regarding educational reform. The most radical education reform was The National Education Act 1999, which was implemented between 1999 and 2002. The Act firstly enhanced lifelong learning and aimed to transform a traditional teacher-centre approach to an innovative learner-centre one with the aid of technology. Due to this Act, numerous international programs in nearly all fields have been offered and Communicative Language Teaching (CLT), in cooperation with other approaches (e.g. computer-assisted language learning, integrated language learning, cooperative learning, project-based learning), was adopted and widely used in CLT enhancement programs. In addition, numerous efforts have been added up to promote the CLT in the Thai context.

However, the outcomes are still far from satisfaction and Thailand is still marked as a nation of "very low proficiency" as it was before the Act. As a result, in 2014, Thailand's Ministry of Education launched policy on English Education Reform to enhance education quality and improve learners' English proficiency. The aims of this policy are to 
develop language skills and promote self-directed learning for selfdevelopment, which will later on turn into increasing of country competitiveness and prepare learners for ASEAN dynamic. The implementation of this policy is still in progress and the outcomes of life-long learning can be assessed in the long run. A more practical approach that Thailand should consider in order to gain insights for policy improvement in the future is to learn lessons from other countries, especially the best practices which will shed lights to Thailand education reforms to some extent. This present study, therefore, explored this issue under the title "Lessons from Best Practices for English Language Educational Reform in Thailand" with the following research question:

1) What is the education of the best practices from the countries where digital technology is being used to drive the English education in Thailand?

2) What are the key points from the selected best practice countries?

\section{Purposes of the Study}

This study primarily aimed to explore the education system of the best practices that integrate digital technology as part of education reform with the purpose to draw some lights to education reform in the age of digital Thailand, with three specific purposes of this study, which were to:

1) Extract and describe education of the best practices from the countries where digital technology is being used to drive or support English education and

2) Identify key points from the selected best practice countries.

\section{Research Methodology}

This was a documentary study. This study began with a review of literature of selected counties on issues under study (e.g. policy, key success factors, applications of technology into ELT and implications). To select the best practices, this study began with a review of literature and then 20 countries were listed. The countries on the list were purposefully drawn for a variety of reasons with regard to the main purpose of the study, integrating digital technology to drive or support 
English education at the national level for decades and also notably achieving high quality of education in all areas, especially English education. For instance, Finland was ranked no. 1 by the Programme for International Student Assessment (PISA)in 2000. Norwegian education system has been considered as one of the world's best with respect to development and educational use of ICT in teaching and learning.There is a widespread perception that the Dutch are multilingual and 'good at learning English'and, indeed, the Netherlands scores highly on the EF English Proficiency Index. (Law, 2007). Lastly, South Korean's performance on international tests (e.g. PISA)has been high in all areas. These four selected countries rank relatively high in PISA 2016.

On the data collection, the analysis extracted the document to describe key success factors in integrating digital technology into English classroom that could help increase national competitiveness in preparation to enhance Thai students' English proficiency for ASEAN dynamic preparation. The conclusion of the study was drawn from an interpretive analysis and synthesis of the review of literature on the issues.

The reliability and validity check was conducted by a data audit that was concerned with an examination of the data and analysis procedures. On reliability check, the list was sent to 10 educators who played a vital role in English education reform in Thailand. Countries on top of the consensus were selected as representatives of the best practices which included Finland, Norway, the Netherlands, South Korea, and Hong Kong. On validity check, the results of the decoded data were drawn from comparisons of three researchers.

\section{RESULTS OF THE STUDY}

The presentation of the results is based on the research question of what kind of best practices from the countries where digital technology is being used to drive the English education in Thailand? The result of this research question aimed to provide general information of education systems of the selected countries and lead to the insight of their educational systems in the next part. The 
description includes these countries: Finland, Norway, the Netherlands, South Korea, and Hong Kong respectively.

\section{Finland}

Finland has been well known for its unique education system. The transformation of the Finland's education system began more than 40 years ago as the key propellant of the country's economic recovery plan. In-country educators had little idea it was so successful until 2000, when the first results from the Programme for International Student Assessment (PISA), a standardized test given to 15-year-olds in more than 40 global venues, revealed Finnish youth to be the best young readers in the world. The country has consistently ranked high in PISA score. ${ }^{2}$ On top of this, Finland's tertiary education has moreover ranked first by the World Economic Forum ${ }^{3}$, proving that their basic education is key milestone for this remarkable success.

With this significant accomplishment, the Finnish Ministry of Education attributed its success to the three key components: ${ }^{4}$ ) the education system, 2) competent teachers and 3) autonomy given to schools. The compulsory education system in Finland consists of a nine-year comprehensive school from $1^{\text {st }}$ to $9^{\text {th }}$ grades, from the ages of 7 to 16 , in which attendance is mandatory. Kindergarten up to tertiary level are exclusively funded and administered by the local governments. According to Special Report from Smithsonian Magazine ${ }^{5}$, Finland has no mandated standardized test for its students, apart from one examination at the end of students' senior year in high

\footnotetext{
${ }^{2}$ Hallamaa, Teemu 3 December 2013). "Pisa-tulokset julki: Suomi pudonnut matematiikassa 10 sijaa yhdeksässä vuodessa". YLE Uutiset in Finnish). Retrieved 7 April 2014

${ }^{3}$ Global Economic forum. The Global Competitiveness Report 20132014 (PDF). Global Competitiveness Report. Retrieved 9 May 2014.

"Background for Finnish PISA success"

${ }^{5}$ http://www.smithsonianmag.com/innovation/why-are-finlands-schools-successful49859555/?no-ist
} 
school. In addition, there is no ranking, no comparison, or competition among students, schools, or regions. The people in the government agencies who are running educational system, from national officials to local authorities, are educators, not business people, military leaders or career politicians. Every school has the same national goals drawn from the same pool of university-trained educators. The result is that a Finnish child has a good shot at getting the same quality education no matter whether he or she lives in a rural village or a university town. The disparities between weakest and strongest students are the smallest in the world, according to the most recent survey by the Organization for Economic Co-operation and Development (OECD). "Equality is the most important word in Finnish education. All political parties on the right and left agree on this," said Olli Luukkainen, president of Finland's powerful teacher's union.

\section{Norway}

According to Norwegian Ministry of Education, out of country's total population, more than 900, 000 people are currently undergoing education or training. In addition to this number, approximately 1 million people participate in adult education courses each year. Education in Norway costs 6.6 per cent of the gross domestic product, while the average for the OECD countries is 5.9 per cent (2003).

Education in Norway is mandatory for all children at age 6-16. The Norwegian school system can be divided into three parts including:

1. Elementary School - Ages 6-13

2. Lower Secondary School - Ages 13-16

3. Upper Secondary School - Ages 16-19

Norway's legislation allows the public funding of privately managed schools like Finland does. According to Ministry of Education, ICT is an integrated instrument for innovation and quality 
development in Norwegian education, based on organizational and working methods that promote learning and innovation. This has made Norwegian education system one of the world's best with respect to development and educational use of ICT in teaching and learning.

\section{South Korea}

The driving force behind the astounding growth of Korea is "education", as the Korea Educational Development Institute proclaims on its website. ${ }^{6}$ Korea has been a remarkable success story in education over the last few decades, achieving a 99 per cent literacy rate and high enrolment rates in higher education: 50 percent of the 18-21 age group is enrolled in four-year degree programmes. Performance on international tests such as PISA is routinely high in all areas.

\section{The Netherlands}

The Netherlands scores highly on the EF English Proficiency Index and, indeed, there is a widespread perception that the Dutch are 'good at learning English'. (Law, 2007) Also, Dutch performance on international tests such as PISA is strong, with a high degree of equality. The Dutch School Inspectorate (2013) reports, for example, that 97 percent of all the 6,807 primary schools reach the basic quality standards and that 83 percent of the100,200 teachers are proficient in all the basic skills.

Success in primary English teaching seems to be attributable as much to general education factors as it is to anything specific to the teaching of English. Indeed, it is only in access to English in out-ofschool contexts that the Netherlands appears to have an edge that is specific to the language.

All mentioned-above is the description of the best practice countries which portrays the general ideas of their educational systems. Below are the details of key points that explain the success of the countries.

\section{${ }^{6}$ http://eng.kedi.re.kr}




\section{Finland:}

1. Finland's education requires no tuition fees and offer fully subsidized meals served to all full-time students. These attracting offers cause no financial pressure to the parents and allow students to fully commit to their studies, instead of worrying their financial needs to pursue their education.

2. There is no "gifted" program.

3. More advanced students are expected to help those who are slower.

4. Finland constructs a publicly funded comprehensive school system without selecting, tracking, or streaming students during their common basic education. ${ }^{7}$

5. Private schools are allowed to be built, however the use of tuition fee is still strictly prohibited and selective admission is not allowed. Private schools are required to admit all the kids on the same basis as the schools administered by local governments. Additionally, private schools must give their students all the education and social benefits that are offered to the students of municipal schools.

6. Small class size, generally below 20 students. ${ }^{8}$

7. School and classroom atmosphere is made to be relaxed and informal style.

8. Homework is minimal to leave room for extra-curricular activities. $^{9}$

$7_{\text {"Ari Antikainen \& Anne Luukkainen of the Department of Sociology, University }}$ of Joensuu, Finland, "Twenty- five Years of Educational Reform Initiatives in Finland".

${ }^{8}$ "The Hechinger Report", "What We Can Learn From Finland: A Q\&A with Dr. Pasi Sahlberg" (December 9, 2010)"

${ }^{9}$ Asked about the many hours Asian students spend in school, Dr. Pasi Sahlberg, of Finland's Education Department told Justin Snider of the Hechinger Report (December 9, 2010:" There's no evidence globally that doing more of the same 
9. Reading for pleasure is actively encouraged; the studies show that Finland publishes more children's books than any other country.

10. During the first years of comprehensive schools, grading may be limited to verbal assessments rather than formal grades. The start of numerical grading is decided locally and there is no high-stakes or attest that to make important decisions about students.

11. It is also possible to divide the scale further with $1 \frac{1}{2}$ ', which represents a half grade, and '+' and '-', which represent one-fourth a grade better or inferior. The grade '10+' can also be awarded for a perfect performance with extra effort by the student.

12. It is considered far preferable to provide a struggling student with extra help and tutoring rather than retaking the year as the first choice. When the decision of repeating/retaking the year arise, interviews between students, parents, teachers and headmaster will be conducted.

13. Both primary and secondary school teachers must have a master's degree to be qualified.

14. Teaching is a respected profession and admission to faculty of education in tertiary level is highly competitive. A prospective teacher must have very good grades prior to their job enrollment.

15. A foreign language is part of the national core curriculum; the choice of language is left to the school; 90 percent of schools choose English.

16. English instruction usually starts at Grade 3 but may also start since Grade 1.

17. English teachers are free to decide on their own teaching methods to implement the Basic Education Curriculum.

18. English teachers are free to choose their own teaching materials.

[instructionally] will improve results. An equally relevant argument would be, let's try to do less. Increasing time comes from the old industrial mindset. The important thing is ensuring school is a place where students can discover who they are and what they can do. It's not about the amount of teaching and learning." 
19. English has increase presence in the environment due to economic globalization such as television programmes, digital media, radio programs and press.

\section{Norway:}

1. Norway ranks high average student attainment rate, behind only Australia and New Zealand according to UNESCO. ${ }^{10}$

2. English is a compulsory foreign language from grade 1 . In the lower secondary school students can in addition choose between another foreign language and in-depth studies in Norwegian or English or Sami.

3. Norwegian education institutions are required to have access to high quality infrastructure and services. The learning arenas are to have technical equipment and Internet connections with adequate bandwidth.Development and use of ICT in learning work are to be supported by secure and cost-effective operative solutions.

4. Digital competence is central to the education at all levels. All students in and outside schools and universities/university colleges must be able to use ICT in a secure, conversant and creative manner so as to develop the knowledge and skill they need in order to be full participants in the community.

\section{South Korea:}

1. English is seen as an essential component of educational success to the extent that South Koreans spend an average of 20,000 hours between primary school and university learning English, including both school instruction and private tutoring'. (EF, 2013 Report)

2. In 2005 Koreans spent 15 billion dollars on private tuition in English (Song, 2011) which made Korea's pursuit of English is probably unparalleled elsewhere in the world. This is set within a context of intense commitment to education as a whole.

\footnotetext{
${ }^{10}$ http://data.uis.unesco.org/
} 
3. Teaching remains a high-status profession which is well-paid currently the ratio of primary teachers' salaries to the earnings of other full-time workers with tertiary education is 1.34, significantly above the OECD average of 0.82 (OECD, 2013b)

4. The commitment of the government to improving primary English language teaching is admirable such as redressing the problem of low language levels among serving teachers, the Ministry of Education, Science and Technology (MEST) has made available a wide range of in-service courses for teachers. These are both short term, usually in school vacations, and long term in the shape of a six-month full-time course with an overseas component in an English-speaking country.

\section{The Netherlands:}

1. Though the age for children to begin learning a foreign language (not necessarily English) is set at age ten, most schools in the Netherlands now introduce English as the first foreign language in Year 1.

2. Schools have a great deal of autonomy in how they organize English instruction and only the number of hours of instruction that learners must receive by the time they exit Year/Grade 8 is stipulated.

3. ELT Teaching methods and use of materials are not specified but left to the discretion of the school.

4. This is a notable achievement and one which many countries would be proud of.

5. Dutch government has setout its plans for quality improvement in teaching2020as a strong profession (Ministry of Education, Culture and Science, 2011) with a number of recommendations designed 'to make the teaching profession more attractive, not only in terms of salary and career earnings potential, but in terms of the quality and status of the profession. 


\section{CONCLUSION}

Two conclusions can be drawn from the results of the study. In general, key success that all these best practice countries share included these ten points: free, accessible, equalized education, ICT in English education, starting learning English in early age, professional development for teachers, stress on qualification of teachers, teacher compensations and welfares, small class size, assessment and testing reform and homework reform.

In details, the ten points falls into 3 categories: first, all best practice countriesprovide free, accessible, equalized education, 2) ICT in English education, 3) English education in early age and 4) professional Development for teachers. Second, three of the four countriesstress on 1) qualification of teachers, 2) teachers compensations and welfares, 3) small class size and 4) assessment and testing reform. Lastly, only Finland which is on top in all areas applies homework reform.

Thailand's English language education reform should take these points into consideration in policymaking in the future ifit wants to reach the educational efficiency of the best practice countries.

\section{REFERENCES}

de Segovia, L. P., \& Hardison, D. M. (2009). Implementing education reform: EFL teachers' perspectives. ELT journal, 63(2), 154162.

Ella, Rechele Ballovar, and Richel C. Dapudong. "Oral Communication Achievement of the Bachelor of Arts Students Major in English at Rajamangala University of Technology Lanna, Thailand." International Journal of Academic Research in Progressive Education and Development 3.4 (2014): 209-224.

Education First. (2015). EF English Proficiency Index 2015. Retrieved from http://www.ef.co.th/epi/English Institute, Office of the Basic Education Commission. ( 2014). Guidelines for the new English classroom management. Bangkok: Ministry of Education 
Kirkpatrick, R. (2012). English education in Thailand: 2012. Asian EFL Journal, 61, 24-40.

Methitham, P., \& Chamcharatsri, P. B. (2011). Critiquing ELT in Thailand: A reflection from history to practice. Journal of Humanities, Naresuan University, 8(2), 57-68.

Wiriyachitra, A. (2002). English language teaching and learning in Thailand in this decade. Thai TESOL Focus, 15(1), 4-9. 